Article

\title{
Resource Harvesting through a Systematic Deconstruction of the Residential House: A Case Study of the 'Whole House Reuse' Project in Christchurch, New Zealand
}

\author{
Atiq U. Zaman ${ }^{1, *(1)}$, Juliet Arnott ${ }^{2}$, Kate Mclntyre ${ }^{2}$ and Jonathon Hannon ${ }^{3}$ \\ 1 School of Design and the Built Environment, Curtin University, Perth, WA 6102, Australia \\ 2 Project Member of the Whole House Reuse, Rekindle, Christchurch 7670, New Zealand; \\ juliet@rekindle.org.nz (J.A.); mc.katelouise@gmail.com (K.M.) \\ 3 Zero Waste Academy, Massey University, Palmerston North 4442, New Zealand; j.b.hannon@massey.ac.nz \\ * Correspondence: atiq.zaman@curtin.edu.au; Tel.: +61-08-9266-9018
}

Received: 3 September 2018; Accepted: 23 September 2018; Published: 26 September 2018

\begin{abstract}
This study analyzes the case study of a deconstruction project called the 'Whole House Reuse' (WHR) which aimed, firstly, to harvest materials from a residential house, secondly, to produce new products using the recovered materials, and thirdly, to organize exhibition for the local public to promote awareness on resource conservation and sustainable deconstruction practices. The study applies characterization of recovered materials through deconstruction. In addition to the material recovery, the study assesses the embodied energy saving and greenhouse gas emissions abatement of the deconstruction project. Around twelve tons of various construction materials were harvested through a systematic deconstruction approach, most of which would otherwise be disposed to landfill in the traditional demolition approach. The study estimates that the recovered materials could potentially save around 502,158 MJ of embodied energy and prevent carbon emissions of around $27,029 \mathrm{~kg}\left(\mathrm{CO}_{2 \mathrm{e}}\right)$. The deconstruction could eventually contribute to New Zealand's national emission reduction targets. In addition, the project successfully engages local communities and designers to produce 400 new products using the recovered materials and exhibits them to the local people. The study concludes that there is a huge prospect in regard to resource recovery, emission reduction, employment, and small business opportunities using deconstruction of the old house. The sociocultural importance of the WHR project is definitely immense; however, the greater benefits of such projects are often ignored and remain unreported to wider audiences as most of the external and environmental costs are not considered in the traditional linear economy. It is acknowledged that under a favorable market condition and with appropriate support from local communities and authorities, deconstruction could contribute significantly to resource conservation and environmental protection despite its requirement of labor-intensive efforts.
\end{abstract}

Keywords: residential house; deconstruction; resource harvesting; whole house reuse; circular economy

\section{Introduction}

The world is using its natural resources at an ever-increasing rate and the annual extraction of primary materials was around 70,000 million tons in 2010 including minerals, ores, biomass, and fossil fuels, which tripled during 1970 to 2010 [1]. The circulation of global primary materials though trade has also grown at an ever-increasing rate over the past four decades and around 10 billion tons of materials were exported globally in 2010 [2]. This rate of resource consumption is not sustainable in the future, given that people in developing countries aspire to enjoy a standard of living similar to 
that of the world's developed economies. Given the current resource consumption rates, resource efficiency is a critical priority in the global waste policy agenda and forms a major part of Sustainable Development Goals (SDG). The UNEP's recent report (2016) suggests that decoupling of material use and environmental impacts is a key imperative of modern environmental policy [2].

Further material recovery and reuse from waste has the potential to ease the future demand stress and high dependency on further extraction of primary materials from the natural environment. A common rhetoric is "We can't recycle our way to 'zero waste"" [3]. Even a very circular economic system is still likely to be highly dependent on our natural extraction. A study shows that even with aluminium collection and preprocessing rates as high as $97 \%$ each (which is very high compared to current rate of aluminium collection of $49 \%$ ), respectively, combined with $97 \%$ recycling process efficiencies in the smelting process, only $16 \%$ of the aluminium remains utilized in the material lifecycle after 10 years [4]. Hence, resource recovery connected to direct reuse potentially offers a higher efficiency and less associated pollution and energy use, which is very important in every stage of resource consumption and waste management. Waste from construction and demolition (C\&D) provides the highest percentage contribution to the total waste stream relative to other contributing sources such as household, institutes, etc. Hence, this study covers an in-depth investigation of an alternative solution to the issue of C\&D waste management.

At the end of World War II, Australia, as well as other parts of the world, experienced a significant 'construction boom', which appears indicative of the global post-war growth phenomena of the consumption of construction materials worldwide [5]. The major concerns related to the growing demand of construction materials are (i) adverse environmental impacts during the acquisition of building materials and massive waste production during construction; (ii) end-of-use demolition phases; and (iii) the associate greenhouse gas (GHG) emissions across the production-consumption lifecycle. It was found that the built environment in developed countries can be attributed with $40 \%$ of energy consumption, $38 \%$ of GHG emissions, and $40 \%$ of solid waste generation [6].

A typical residential house can be expected to last for an average of 50 years and at the 'end-of-life' phase, the old structures require a major refurbishment or need to be demolished for new development [7,8]. Around 200,000-300,000 buildings are demolished in the United States each year, which would significantly contribute $(\sim 90 \%)$ to the generation of total C\&D waste of 534 million tons annually $[9,10]$. Demolition generally takes place at the end-of-life phase of a residential building. The traditional demolition of building process often involves a rapid knock-down of buildings using heavy machineries without caring much about waste materials. As a result of this damaging and value destroying process, most of the demolition waste is generally consigned to lineal disposal pathways such as landfill and or incineration (with or without energy recovery-W2E). The term "deconstruction" refers in this article as 'building', 'house', or 'home' deconstruction. Diyamandoglu \& Fortuna [11] define deconstruction as the process of disassembling a physical structure to its components in reverse order to that used during construction with minimum damage so that they maintain their original physical properties and structural integrity. Therefore, the deconstruction of building i.e., "systematic disassembly of buildings in order to maximize recovered materials reuse and recycling" involves carefully taking apart portions of building or removing their contents with the primary goal of reuse in mind [12,13]. Often, a labor-intensive manual method is applied in the deconstruction process due to a lack of technology-driven automated system for material collection and to ensure a maximum resource recovery opportunity of the manual work [14].

This study aims to conceptualize the key challenges and opportunities associated with applying deconstruction of residential buildings in a New Zealand context. The study analyses the material harvesting potential and the resulting environmental benefits by considering the embodied energy savings and avoided carbon dioxide emissions from the recycled materials. In addition, the study analyses the socioeconomic benefits and also investigates the key challenges of the deconstruction activities in New Zealand. The study considers a deconstruction project entitled "Whole House Reuse" (2013-2015) as a case study, and seeks to propose a number of recommendations for the development 
of comprehensive strategies for deconstruction practices in the Pacific region. At this point it is useful to clarify that the case study 'whole house reuse' (WHR) project involves whole house deconstruction coupled to the aspiration of entire material reuse. As such, this project can be distinguished from the concept and practice of whole house reuse (also commonly referred to as whole house recycling), whereby the entire structure or building is literally jacked up, put on a truck, and relocated so as to be reused (albeit often repaired, renovated, or refurbished, redesigned, and repurposed) in various degree of its original format.

\section{The State of Construction and Demolition (C\&D) Waste Management in New Zealand}

Approximately 850,000 tons of C\&D waste is sent to landfills each year in New Zealand. However this estimate varies, depending on the level of building activity [15]. Historically the previous New Zealand Waste Strategy (NZWS:2002) entitled 'Towards Zero Waste and a Sustainable New Zealand' established targets for all Territorial Authorities to measure C\&D waste and to set local diversion goals (2005), and nationally, for a 50\% reduction, by weight, of C\&D waste going to landfills by (2008) [16]. However, these targets were nonenforceable and were not well supported by the requisite framework of legislation, policies, programs, and regulatory- and market-based economic instruments needed to drive achievement $[16,17]$.

Under the pretext that they were "not able to be measured or achieved" [18] the subsequent NZWS:2010 abandoned not just the C\&D related targets, but also all 28 other waste minimization targets and with this the transparent aspiration and accountability that targets are recognized as providing [19]. Whilst the development of the Waste Minimization Act (WMA:2008) provided mechanisms for improving waste data, one of the key challenges in seeking to better manage or minimize C\&D waste in New Zealand is that national data collection and reporting remains poor [20]. Whilst recognizing the inconsistency and incompleteness of data in this sphere, recent estimates put $C \& D$ at $17 \%$ of total MSW and identify the lower cost per ton disposal charge applying to C\&D relative to MSW as an enabler landfill rather than resource recovery [16]. The C\&D waste in New Zealand mainly consists of timber $(38 \%)$, concrete and cleanfill $(25 \%)$, plasterboard $(18 \%)$, metal $(6 \%)$, organic $(2 \%)$, paper $(3 \%)$, glass $(1 \%)$, plastic $(1 \%)$, and other construction materials $(6 \%)$ [21,22].

Table 1 provides an overview of the legislative-regulatory and strategy-policy environment designed to influence and control waste recycling and disposal activities, including C\&D waste management in New Zealand. Surrounding and integrated with this formal statutory framework, Farrelly \& Tucker articulate the concept of the New Zealand "wastescape" as inclusive of parameters, such as key national and local government waste and resource management policy, planning and program frameworks, formal supranational waste and associated environmental conventions, and voluntary accords of which New Zealand is a signatory, singular and collective business sector waste minimization commitments and initiatives, nongovernmental organizations and their vision, strategies, and activities, individual and group awareness, understanding and actions, the evolving nationwide rubric of surveys, monitoring and reporting, environmental education and behavior change initiatives, research, development, and intellectual property, and environmental technologies and infrastructure and their related product and service systems, all of which is enlivened by shared community values, beliefs, and cultural formation [23]. The state of the waste management in New Zealand, as described by key parameters and reported locally and to the likes of the OECD, is a net outcome of the statutory framing, the permutation of this complex 'wastescape' overlain with sometimes quite stark shifts in the mixed member proportional (MMP) political ideology elected to the levers of power $[19,23]$.

The Resource Management Act (RMA 1991) is the main piece of legislation framing how the effect of activities, in this instance disposal and recycling facilities, impact the environment and how they should be managed. Prior to the Waste Minimization Act (WMA:2008), which reorganized and clarified the operability of the Local Government Act (LGA:2002), this legislation identified solid waste as the core service relevant to the empowerment and democratic function Local Councils in prompting 
environment, social, cultural, and economic wellbeing of their communities. In respect the subject of this article this cohort alongside the Building Act (2004) and the Waste Minimization Act (WMA:2008) might be expected to guide the sustainable use of construction materials and reduction of C\&D waste during construction phase and minimize waste disposal to landfill [15]. Specifically, the purpose of the WMA (2008) is to encourage waste minimization and a decrease in waste disposal in order to (a) protect the environment from harm and (b) provide environmental, social, economic, and cultural benefits [24]. A core requirement of the WMA:2009 is for local Councils to regularly undertake formal 'waste assessments' and to utilize this data in the developed of 'waste minimization and management plans' (WMMP) which are required to be submitted to the New Zealand Ministry for the Environment for approval. A key opportunity enabled in the WMA:2009 legislation is for the Minister of the Environment to designate 'priority' products, and in doing so, to require the associated producer to develop and have accredited a product stewardship scheme in order to manage environmental externalities, for example end-of-life collection treatment and recycling. To date, no types of material, product, or packaging have been designated a 'priority product' and, accordingly, New Zealand does not have any mandatory product stewardship schemes accredited.

In 2009, the Waste Minimization Act enabled the introduction of a national waste disposal levy of $\$ 10$ per ton (plus GST) on all waste disposed of at disposal facilities to raise revenue to promote and achieve waste minimization and to recognize the cost of waste disposal on the environment, society, and the economy by increasing the cost of waste disposal [18].

Table 1. Regulations and strategies related to waste, recycling, and specifically C\&D management in New Zealand.

\begin{tabular}{|c|c|c|}
\hline Legislations/Policy/Strategy & Brief Outlines/Relevance & Sources \\
\hline $\begin{array}{c}\text { The Resource Management } \\
\text { Act } 1991\end{array}$ & $\begin{array}{l}\text { The RMA controls the environmental impacts (e.g., discharges to } \\
\text { land, air, and water) of waste facilities such as disposal facilities, } \\
\text { recycling plants, and clean-fills. The RMA also contains key } \\
\text { sections which give effect to the principles of 'Treaty of Waitangi' } \\
\text { (Te Tiriti o Waitangi) and role of Maori in exercising } \\
\text { 'Kaitiakitanga' (may be translated, in part, as guardianship). }\end{array}$ & {$[25]$} \\
\hline $\begin{array}{l}\text { The Hazardous Substances } \\
\text { and New Organisms Act } 1996\end{array}$ & $\begin{array}{l}\text { Enables regulations controlling the entire lifecycle (including } \\
\text { import, identification, manufacture, use, storage, emergency } \\
\text { management, end-of-life treatment, and disposal (including by } \\
\text { export) of manufactured chemicals that have hazardous } \\
\text { properties. In the context of C\&D this would include for } \\
\text { example, copper chromium arsenic (CCA) timber preservative } \\
\text { chemicals, and the resulting treated timber materials. }\end{array}$ & [18] \\
\hline $\begin{array}{l}\text { The Local Government Act } \\
\qquad 2002\end{array}$ & $\begin{array}{l}\text { Solid waste collection and disposal is identified as a core service } \\
\text { required to be considered by a local authority. }\end{array}$ & [25] \\
\hline $\begin{array}{l}\text { The Climate Change Response } \\
\text { Act } 2002\end{array}$ & $\begin{array}{l}\text { This Act also enables the New Zealand Emissions Trading } \\
\text { Scheme (ETS) which includes, for example, the GHG emissions } \\
\text { arising from landfill. }\end{array}$ & {$[25]$} \\
\hline Ozone Protection Act 1996 & $\begin{array}{l}\text { This Act gives effect to New Zealand's commitments under the } \\
\text { Montreal Protocol, and interfaces with the waste \& recycling } \\
\text { industry via the subject chemicals' presence in the products and } \\
\text { materials managed by the sector. }\end{array}$ & [25] \\
\hline The Litter Act 1979 & $\begin{array}{l}\text { Provides a mechanism for local government action to abate and } \\
\text { control litter (inclusive of on larger scale, 'fly tipping', \& rogue } \\
\text { illegal dumping). In May } 2018 \text { the New Zealand government } \\
\text { the intention and ground work for a 'Zero Carbon Act' and the } \\
\text { establishment of an independent climate change commission. }\end{array}$ & [25] \\
\hline The Building Act 2004 & $\begin{array}{l}\text { The Building Act } 2004 \text { contains sustainability principles } \\
\text { including the efficient and sustainable use of materials and the } \\
\text { reduction of waste during the construction process. }\end{array}$ & [15] \\
\hline
\end{tabular}


Table 1. Cont.

\begin{tabular}{|c|c|c|}
\hline Legislations/Policy/Strategy & Brief Outlines/Relevance & Sources \\
\hline $\begin{array}{l}\text { Health and Safety and } \\
\text { Employment Act } 1992\end{array}$ & $\begin{array}{l}\text { The purpose of this is Act is to prevent work related harm. } \\
\text { This Act interfaces with C\&D operations and waste \& recycling } \\
\text { collection, processing, and disposal activities \& facilities as these } \\
\text { are recognized as hazard rich. }\end{array}$ & [25] \\
\hline $\begin{array}{l}\text { The Waste Minimization Act } \\
\qquad 2008\end{array}$ & $\begin{array}{l}\text { The Waste Minimization Act } 2008 \text { was introduced to encourage } \\
\text { waste minimization and reduce waste disposal by applying } \\
\text { a levy on all waste sent to landfills. }\end{array}$ & [15] \\
\hline $\begin{array}{l}\text { The New Zealand Waste } \\
\text { Strategy (2002-2010) }\end{array}$ & $\begin{array}{l}\text { The NZWS:2002 derived from an assertive and influential zero } \\
\text { waste campaign and represented an environmentally proactive } \\
\text { and holistic approach to waste policy which connected waste } \\
\text { issues to the broader imperative of sustainable development. }\end{array}$ & {$[18,26,27]$} \\
\hline $\begin{array}{l}\text { The New Zealand Waste } \\
\text { Strategy (2010-ongoing) }\end{array}$ & $\begin{array}{l}\text { The two goals of the NZWS:2010-reduce the harmful effects of } \\
\text { waste and improve the efficiency of resource use. Noticeably the } \\
\text { NZWS:2010 was developed subsequent to the WMA:2008 (so is } \\
\text { cognizant of the new faculties offered in this legislation) and in } \\
\text { the aftermath of the GFC and a change from a center left to } \\
\text { center right coalition government. As such, whilst profiled as } \\
\text { providing 'flexible direction' this strategy also reflects the } \\
\text { presiding political ideology of the period and the consequent } \\
\text { emphasis on the primacy of economic growth, amidst the other } \\
\text { required social environmental and cultural considerations }\end{array}$ & {$[18,19]$} \\
\hline $\begin{array}{l}\text { Other voluntary international } \\
\text { agreements }\end{array}$ & $\begin{array}{l}\text { A range of legally binding and voluntary international } \\
\text { agreements: } \\
\text { - } \quad \text { Basel and Waigani Conventions } \\
\text { - } \quad \text { Stockholm Convention on Persistent Organic Pollutants } \\
\text { - } \quad \text { Vienna Convention/Montreal Protocol on Substances that } \\
\text { Deplete the Ozone Layer } \\
\text { - International Convention for the Prevention of Pollution } \\
\text { from Ships (MARPOL)-London } \\
\text { Dumping Convention-1975 } \\
\text { - Protocol to the Antarctic Treaty on } \\
\text { Environmental Protection-1991 } \\
\text { - Rio Declaration on Environment and } \\
\text { Development-Agenda } 21 \\
\text { Framework Convention on Climate Change (FCCC)—Paris } \\
\text { Agreement 2015 } \\
\text { United Nations-led 'CleanSeas' campaign-2018 }\end{array}$ & [25] \\
\hline
\end{tabular}

\section{The Role of Deconstruction in Waste Minimization and Circular Economy}

Rather than demolition and dumping, the deconstruction of the built infrastructure and the conservation, reuse, and recycling of the associated material resources, is identified as central to tackling the high level of waste generated by the $C \& D$ sector associated local environmental and global climate change issues [28]. However, the reuse of materials from deconstruction and disassembly depends on the durability of materials, reachability, and visibility of joints, quality of components at the end-of-life [29-31]. High quality assured, deconstruction is an effective means for reducing construction and demolition waste and reducing GHG emissions at the end-of-life phase of residential house $[28,32,33]$. According to the report published by the International Council for Research and Innovation in Building Construction (ICRIBC), the demolition of a building produces an enormous amount of debris, and deconstruction is emerging as an alternative to demolition as it seeks to maintain the highest possible value for materials in existing buildings by dismantling buildings in a manner that will allow the reuse or efficient recycling of materials [13].

Hoglmeier et al. [34] report that building typology plays a vital role in the ability to successfully harvest resources from the deconstruction process and encourage the view that the built environment 
should be conceptualized as a 'stock' of various material resources stored, pending reincorporation back into new forms of economic utility. In a New Zealand context this potential C\&D derived resource spectrum includes asphalt, clay bricks, roof-tiles, paper, cardboard, wood composites, concrete aggregate, glass and ceramics, various types of metal, hard and soft plastic polymers, plaster board, rubber, soil and rock clean-fill, floor and wall coverings and furnishings, coverings, a range of reusable second hand items/fixtures and fittings, vegetative green-waste, as well as a range of other miscellaneous materials, some of which are hazardous: fluorescent light ballasts, refrigeration and air conditioning equipment, batteries (lead, mercury, and acid) solvent-borne paints and solvents, asbestos insulation (in roof and wall claddings, pipe insulation, some vinyl flooring, textured ceilings, and roofing membrane sheets), lead or materials that contain lead such as pipes flashings, paint, bath, and basin wastes [28,35-37].

Reporting on New Zealand's C\&D waste issues varies widely. Based on what was cited as conservative 1995 data (not including clean-fills) [38], C\&D waste was 17\% of New Zealand landfill waste. Whilst subsequent reporting puts the figure as high as " $50 \%$ of all waste" [39], both commentaries align around the scale of issue and associated the scope of positive environmental opportunity accorded to 'alternative' approaches to C\&D waste management. Today, in total, the current estimated wastage of C\&D resources is reported as 2.15 million tons, made up of $0.85 \mathrm{Mt}$ (landfill) and $1.3 \mathrm{Mt}$ (clean-fill), which represents $26 \%$ of the total waste 7.6 million Mt discarded via these disposal pathways [28].

Despite the reported environmental benefits of deconstruction, it has not been widely implemented in Australia, New Zealand, and other parts of the world. In New Zealand, a wave of interest, reporting, and case studies appear in association with the campaign efforts Zero Waste New Zealand trust and NZWS:2002 era [36-41], but this has been followed by an apparent hiatus in effort and activity in C\&D waste minimization, possibly associated with the abandonment of all targets in the NZWS:2010 [19, 27]. This apparent loss of momentum in addressing C\&D waste issues occurs despite an Auckland based construction case study reporting an achievable $56 \%$ saving in waste (by weight), via "source separation costs which were minimal and easily compensated for by the $19 \%$ saving in waste disposal costs" [37]. Similarly, a six month Christchurch based research trial encompassing four construction projects ( 0.9 to $9 \$ \mathrm{M}$ value), reported as part of the then 'Target Zero Programme', cited $20-40 \%$ waste reduction associated with a 10 to $80 \%$ cost reduction [36]. In 2005, based upon the early series of mostly construction based case studies, a more holistic approach was called for 38]: the 'Resource Efficiency in Building and Related Industries' (REBRI) project was created by developing a set of practical (C\&D) guides that sought to reduce waste through the policy framing of 'resource efficiency' [39-41].

More recent commentary supports the early value proposition which was established in support of proactive environmental approaches to $C \& D$ waste minimization. The Beacon Pathway organization reports "considerable waste diversion ... noticeable savings ... little disruption to business as usual ... " [42] as correlated opportunities. Similarly, LEVEL \& BRANZ (accessed 2018) cite 'Homestar' data in claiming that "at least $50 \%$ can be diverted, and often $60-70 \%$ is achieved" and the New Zealand Green Building Council in reporting that some commercial projects have "diverted $90 \%$ of building site waste". Whilst the construction element of New Zealand's C\&D waste data appears as a key strength, positive approaches/outcomes are also reported as being generated by the demolition deconstruction-reuse sphere by the Auckland Council zero waste 2040 strategy $[28,43,44]$. The findings of the Rekindle WMR project, resonate with and add to this latter element of New Zealand C\&D waste journey to date.

The key objective of deconstruction is to maximize resource recovery at the end of building life cycle, this potentially enables the associated material resources to be reused and recycled and hence offsetting what would otherwise be 'virgin' resource inputs. As such, deconstruction and reuse is a strategic activity which has the potential to significantly improve national resource efficiency and the conservation of finite resource stocks which are key outcomes central to the concept of circular economy $[28,45]$. A circular economy represents an alternative to the existing, predominantly linear, 'take-make-consume-dispose' economic model. The Ellen MacArthur Foundation defines a circular 
economy as one that is restorative, and one which aims to maintain the utility of products, components, and materials and retain their value [46]. The fundamental principles of a circular economy as outlined by the Ellen MacArthur Foundation are as follows. It preserves and enhances natural capital by controlling finite stocks and balancing renewable resource flows; it optimizes resource yields by circulating products, components, and materials in use at the highest utility at all times in both biological and technical cycles (as shown in Figure 1); and it fosters system effectiveness by revealing and designing out the negative externalities.

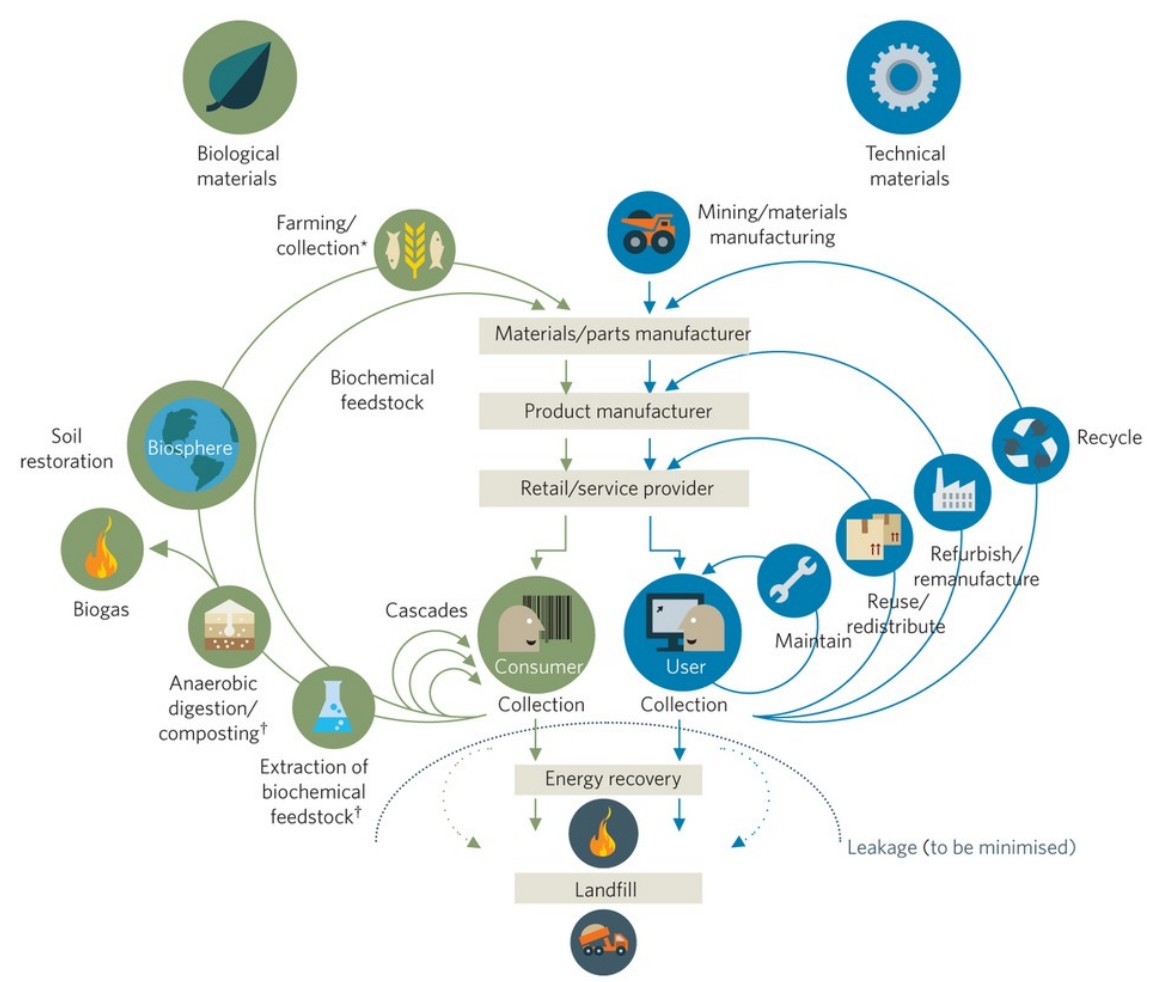

Figure 1. The circular economy-a restorative industrial system by design [46].

Given systemically low rates of resource recovery and material reuse and recycling from waste, the construction industry is one of the main contributors of global resource consumption and environmental pollution. Conversely, developing a deconstruction sector as a strategic national activity promotes a restorative resource management model, which supports the concept of circular economy. There is an opportunity to foster circular economy through deconstruction, reuse, and recycling of material resources from the national housing stock, as the process creates employment opportunities, conserves materials, recovers resources, and circulates materials within the construction industrial system. A parallel opportunity in a restorative circular economic model is to phase out negative externalities (such as emissions and environmental pollution) through sustainable design and construction practices, with the aim that there is no leakage in system and no waste for landfill.

\section{The Key Challenges and Barriers of Building Deconstruction}

Deconstruction and reuse of building materials offers a number of environmental, community, and economic benefits. After these benefits were realized, the Building Materials Reuse Association was formed in 1994 in Canada and also became a US-based organization in 2004 [47]. However, significant progress has not been made institutionalizing the deconstruction method. Only a number of studies have been conducted in the form of pilot project and case study analysis to investigate the key challenges and barriers of deconstruction process. Dantata et al. [33] conducted a study of six wood-framed residential structures in Gainesville, Florida; the study found that deconstruction 
costs could be $17-25 \%$ higher than demolition costs due to labor cost, disposal cost (tipping fee and transportation), and the resale value of deconstructed materials.

Studies conducted in the USA $[48,49]$ show that, although deconstruction costs approximately $26 \%$ compared to demolition, it saves approximately $37 \%$ for deconstruction over demolition with a conservative salvage value (excluding materials storage, inventory, and sales personnel costs). One of the key reasons of applying demolition instead of deconstruction is because it involves less money, labor, and time.

Diyamandoglu and Fortuna [11] analyzed material recovery and environmental impacts of deconstruction of a wood-frame house in Vermont, USA. The study found that wooden materials and steel contributed to the highest reduction in emissions and energy. The deconstruction study conducted by Falk [50] in the USA identified that one of the major technical barriers of reusing dimensional lumber in construction industry and the quality control was the critical element in the acceptance and trade of recovered lumber products. Denhart [51] conducted a study on deconstruction programs in the USA soon after hurricane Katrina hit in 2005. The study reported on the reclaimed materials from four deconstructed houses. A total of 44 tons of material was redirected back into the local building material stream (enough to build three new homes out of the four that came down). The study showed that the cost/profit of deconstruction varied from a net cost of $\$ 3.80$ to a net profit of $\$ 1.53$ per square foot, compared to an estimated net cost of demolition at a steady $\$ 5.50$ per square foot.

Forsythe [52] conducted a study on housing demolition and timber waste recovery in Australia and showed that demolishers' decision-making influences a number of aspects such as site safety, productivity, economic of scale, market value, and supply chain entrepreneurship. In addition, the project specific drivers including recurring cost versus income equates those impacts on the viability of project level decisions.

Based on the previous studies on deconstruction, it can be asserted that deconstruction process is a labor intensive and costly practice and it requires more time compared to traditional demolition of buildings. Despite various environmental and socioeconomic benefits, demolition is still a favorable option under the current waste market and business conditions. This study tries to investigate how deconstruction could be a viable option for resource recovery under alternative approaches. In addition, the study links deconstruction with the concept of circular economy.

\section{Materials and Methods}

Most of the previous studies of deconstruction address the possible environmental and economic benefits of construction material recovery [30] and very little attention is given to the principles of deconstruction and social aspects. This study tried to investigate the environmental as well as socioeconomic benefits of the 'Whole House Reuse' (WHR) project facilitated by Rekindle (see: https:/ / www.rekindle.org.nz). Although a whole-life cycle consideration of the building would be better, this study mainly focuses on the material recovery potential and subsequent socioeconomic and environmental benefits and challenges of the deconstruction approach.

Various construction materials were recovered during the deconstruction process and all materials were cataloged based on the article type, volume of the materials and number of units available. A booklet of 'Whole House Reuse: Deconstruction' was prepared. The physical classification and assessment of materials and the potential of materials recovery were determined using the cataloged based on the following criteria presented in Table 2.

Scores from 1 to 10 were used to rate the materials in the context of reusability, reparability, recyclability, and disposal to landfill. A score of 10 means the item could be reused as is without compromising any material value or aesthetic and a lower score means low efficiency in reusability and recyclability. Previous studies have indicated that recycling and resource recovery efficiency are often determined by the amount of personal effort and inconvenience involved $[53,54]$. The study considers the materials which require the lowest level of willingness and efforts to recycle, therefore, the materials that scored 5 or more were considered in the analysis of environmental benefits. 
Table 2. The scores used to characterize cataloged materials.

\begin{tabular}{ccc}
\hline Scale (1-10) & Description & Interpretation \\
\hline 01 & Disposal/landfill & Not suitable for recycling/composting \\
02 & Composting & Suitable for biodegradation \\
03 & Low recyclability & Recycle requires high efforts \\
04 & Medium recyclability & Recycle requires medium efforts \\
05 & High recyclability & Recycle requires low efforts \\
06 & Repair requires high efforts & Substitutes functions with high efforts \\
07 & Repair requires low efforts & Substitutes functions with low efforts \\
08 & Reuse for alternative purposes & Replaces other functionalities \\
09 & Reuse as is & Substitutes similar functions \\
10 & Reuse as is & Substitutes similar functions and aesthetics \\
\hline
\end{tabular}

\subsection{Measuring the Environmental Benefits of Harvested Materials}

There are many methods available for assessing the environmental impacts of materials and components within the building sector and often the life cycle assessment (LCA) tools are being used to evaluate the environmental loads of processes and products during their whole life cycle. However, this study only focused on the environmental benefit in relation to the embodied energy savings and carbon emission reduction. The study assumes that the harvested high-quality materials from the deconstruction process would be used again for construction or for manufacturing new products, which means the same amount of the material (virgin or mixed materials) will be substituted by the recovered materials which eventually saves embodied energy and avoids carbon emission. Therefore, the scope of the environmental analysis of this study was limited to the material recovery phase and the study did not consider the whole life cycle phases including transportation, distribution, use and disposal phases.

The environmental benefits of the harvested materials were calculated based on energy and associated carbon dioxide emission reduction to the atmosphere. The study used the Inventory of Carbon and Energy (ICE) database to calculate the embodied energy and carbon emission reduction from the recovered materials used in Table 3. The calculation used in the ICE database is considered for the geographical context of United Kingdom. Since there is no similar database for the context of New Zealand, the study assumed a similarity between the UK and New Zealand contexts and therefore, the authors acknowledge an associated margin of error may exist in the calculations. However, in providing indicative findings, the research meets the underlying objectives of the article, which is to initiate discussion around the value of conducing further research to quantify benefits of deconstruction approaches such as illustrated in the WHR project.

Table 3. The embodied energy and carbon emission reduction from C\&D materials [55].

\begin{tabular}{ccccc}
\hline \multirow{2}{*}{ Material Types } & \multicolumn{2}{c}{ Mixed Material } & \multicolumn{2}{c}{ Virgin Material } \\
\cline { 2 - 5 } & Embodied Energy (MJ/kg) & $\left.\mathbf{C O}_{\mathbf{2 e}} \mathbf{( k g} / \mathbf{k g}\right)$ & Embodied Energy $\mathbf{~ M J / k g ) ~}$ & $\left.\mathbf{C O}_{\mathbf{2 e}} \mathbf{( k g} / \mathbf{k g}\right)$ \\
\hline Brass & 44 & 2.64 & 80 & 4.8 \\
Copper & 42 & 2.71 & 57 & 3.81 \\
Aluminium & 155 & 9.16 & 218 & 12.79 \\
Lead & 25.21 & 1.67 & 49 & 3.37 \\
Stainless Steel & 20.1 & 1.46 & 35.4 & 2.89 \\
Bricks & 3 & 0.24 & 3 & 0.24 \\
Ceramic & 10 & 0.7 & 20 & 1.14 \\
Concrete & 0.75 & 0.107 & 1 & 0.15 \\
Glass & 11.5 & 0.59 & 15 & 0.91 \\
Masonry & 1.1 & 0.174 & 1.1 & 0.174 \\
Melamine & 97 & 4.19 & 97 & 4.19 \\
Textile/Fabric & 74 & 3.9 & 74 & 3.9 \\
Plastic & 80.5 & 3.31 & 95.3 & 3.76 \\
PVC & 68.6 & 3.23 & 77.2 & 3.1 \\
Plywood & 15 & 0.45 & 15 & 0.45 \\
Timber & 10 & 0.31 & 16 & 0.58 \\
\hline
\end{tabular}




\subsection{Case Study of the 'Whole House Reuse' Project}

The devastating earthquakes in 2010 and 2011 in Canterbury, New Zealand resulted in 10,000 homes being declared unfit for further occupation and requiring demolition, and by 2014, approximately half of the homes within Christchurch City's 'Residential Red Zone' had been demolished. Traditional demolition which typically crushes and removes materials using a mechanical excavator in a relatively quick and tightly scheduled timeframe, is the most commonly applied method. The affected homeowners in Christchurch commonly describe feeling shocked, alienated, and further traumatized by the destructiveness of the demolition process [56]. The Whole House Reuse (WHR) project was initiated within the context of Christchurch City's postearthquake response, as the antithesis of the prevailing 'frenzy' of destructive demolition and wastage. As such, the project celebrates a thoughtful and resourceful alternative and demonstrates the careful nature of deconstruction, which enables high quality products to be upcycled from salvaged resources. The project was conceptualized as an opportunity to conduct a detailed exploration and examination of the economic, artistic, design, social, cultural, and environmental potential of transformative material reuse that make up one home. Figure 2a shows the deconstruction process of WHR project.

The house selected for deconstruction was located at 19 Admirals Way, New Brighton, Christchurch, New Zealand. The project was facilitated by Rekindle, a local community based environmentally focused NGO, with the support of the Sustainable Initiatives Fund Trust, Creative Communities, and Jamon Construction Ltd. A professional team of salvagers from Silvan Salvage and a team of dedicated volunteers undertook the work of careful, 'piece by piece' dismantling of the house. The recovered items were identified, categorized, quantified, cataloged, and appropriately stored in preparation for the reuse phase of the project.

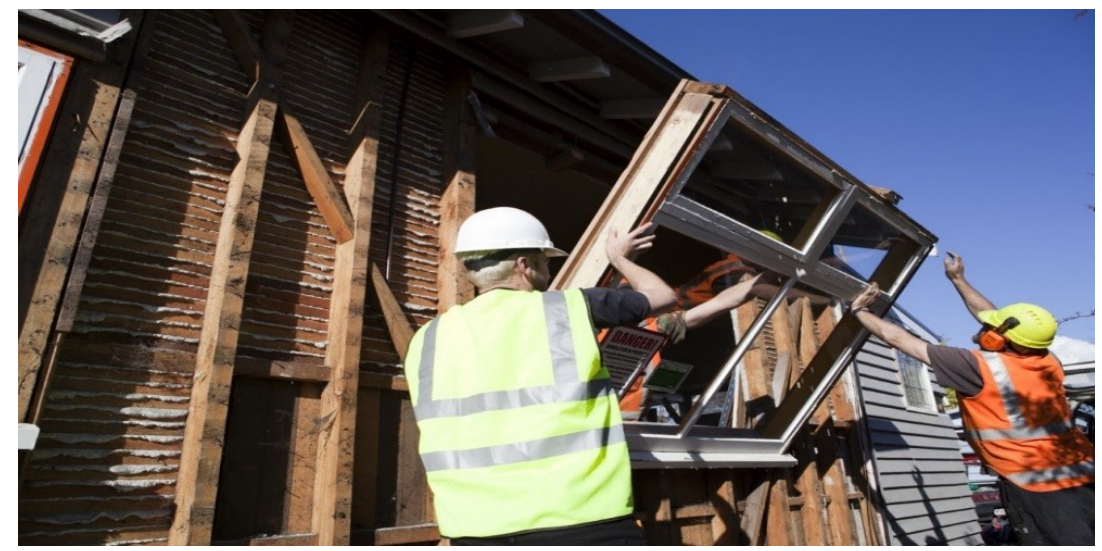

(a)
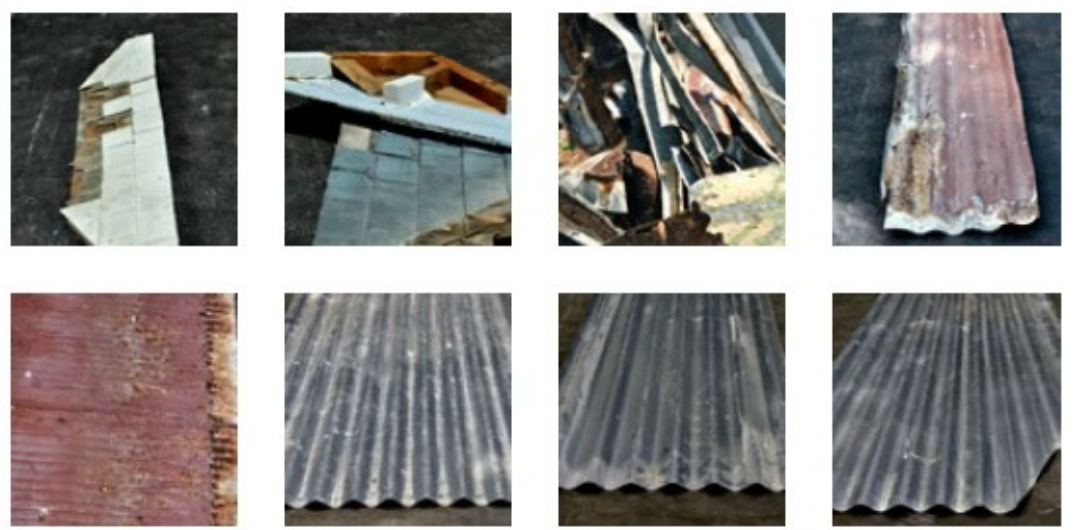

(b)

Figure 2. Deconstruction process (a) and the catalog of harvested resources (b) (Courtesy: Guy Frederick). 


\section{Results and Discussion}

\subsection{Characterization of Harvested Materials}

The cataloged items (Figure 2b) were carefully categorized based on physical assessment of the quality of the harvested materials and level of reusability, reparability, and recyclability. A total of 480 materials were cataloged. Figure 3 shows the physical rating of various materials. Only $1 \%$ of the materials (mainly shelf units) were rated as 10, meaning that these items/materials could be reused as is, without any compromise in the quality, functionality, and aesthetics of the items/materials. Another $1 \%$ of the harvested materials were scored as 9 (mainly timber and hardboard materials), which means that these items can be utilized in serving a purpose of similar quality and functionality. Approximately $7 \%$ of cataloged materials were scored as 8 (i.e., "Replaces other functionalities"), whilst most of the materials were scored between 5 and 7 (around 70\%), indicating that a significant amount of construction materials (around 79\%) can be harvested through deconstruction process and can potentially be recirculated in the consumption supply chain by the demonstrated reuse, repair, and recycle practices.

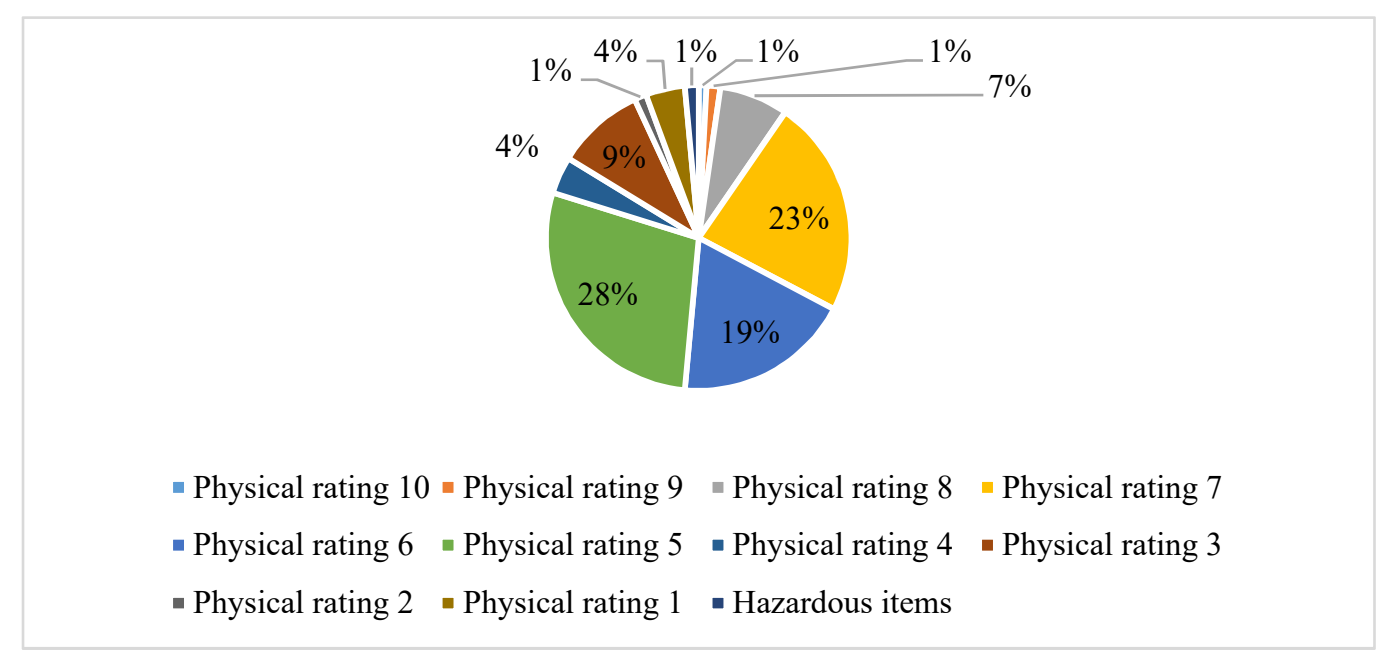

Figure 3. Physical rating of various harvested materials.

A number of studies $[57,58]$ indicate that successful recycling practices require willingness and effort. Thus, this study considers all those materials that require low efforts as rated 5 or above, based on the assumption that under current recycling practices these items would potentially be relatively easily recycled instead of being disposed of in landfill. Table 4 shows the various types of materials recovered through deconstruction, which can be considered as having a relatively high recycling and material value. A total of 12,053.5 kilogram of various materials (scored above 5) were harvested; mainly from timber (58.1\%), bricks (24.16), and aluminium (14.16\%). 
Table 4. List of harvested materials.

\begin{tabular}{ccc}
\hline \multirow{2}{*}{ Harvested Items } & \multicolumn{2}{c}{ Amount of Harvested Materials } \\
\cline { 2 - 3 } & In kg & In per cent (\%) \\
\hline Brass & 2.3 & $0.02 \%$ \\
Copper & 3.4 & $0.03 \%$ \\
Aluminium & 1706.6 & $14.16 \%$ \\
Lead & 0.5 & $0.00 \%$ \\
Stainless Steel & 16.7 & $0.14 \%$ \\
Bricks & 3010 & $24.97 \%$ \\
Ceramic & 45.5 & $0.38 \%$ \\
Concrete & 100 & $0.83 \%$ \\
Glass & 6.5 & $0.05 \%$ \\
Masonry & 5.5 & $0.05 \%$ \\
Melamine & 5 & $0.04 \%$ \\
Textile/Fabric & 6.6 & $0.05 \%$ \\
Plastic & 42.8 & $0.36 \%$ \\
PVC & 6.3 & $0.05 \%$ \\
Plywood & 83.3 & $0.69 \%$ \\
Timber & 7012.5 & $58.18 \%$ \\
Total & $12,053.5$ & $100.00 \%$ \\
\hline
\end{tabular}

\subsection{Environmental Benefits of Harvested Materials}

As described in the methodology, the environmental benefits of harvesting materials through deconstruction were measured by assessing the embodied energy savings and abatement of carbon emission $\left(\mathrm{CO}_{2 \mathrm{e}}\right)$ using the values in Table 3. The 'mixed' material means the item has a preselected recycled content, which is usually available in the market and the 'virgin' materials means the item has been extracted from primary virgin material. Table 5 shows the embodied energy saving and carbon emission abatement of harvested materials though the WHR project.

Table 5. Embodied energy and carbon emission reduction through harvested materials.

\begin{tabular}{|c|c|c|c|c|c|c|c|c|}
\hline \multirow{3}{*}{ Materials } & \multicolumn{4}{|c|}{ Mixed Materials } & \multicolumn{4}{|c|}{ Virgin Materials } \\
\hline & \multicolumn{2}{|c|}{$\begin{array}{c}\text { Embodied Energy } \\
\text { (MJ) }\end{array}$} & \multicolumn{2}{|c|}{$\begin{array}{l}\text { Carbon Reduction } \\
\qquad\left(\mathrm{CO}_{2} \mathrm{e}\right)\end{array}$} & \multicolumn{2}{|c|}{$\begin{array}{c}\text { Embodied Energy } \\
\text { (MJ) }\end{array}$} & \multicolumn{2}{|c|}{$\begin{array}{c}\text { Carbon Reduction } \\
\left(\mathrm{CO}_{2} \mathrm{e}\right)\end{array}$} \\
\hline & MJ & $\%$ & kg & $\%$ & MJ & $\%$ & kg & $\%$ \\
\hline Brass & 101.2 & $0.03 \%$ & 6.1 & $0.03 \%$ & 184.0 & $0.04 \%$ & 11.0 & $0.04 \%$ \\
\hline Copper & 142.8 & $0.04 \%$ & 9.2 & $0.05 \%$ & 193.8 & $0.04 \%$ & 13.0 & $0.05 \%$ \\
\hline Aluminium & $264,518.5$ & $75.37 \%$ & $15,632.2$ & $82.87 \%$ & $372,032.4$ & $74.09 \%$ & $21,827.0$ & $80.75 \%$ \\
\hline Lead & 12.6 & $0.00 \%$ & 0.8 & $0.00 \%$ & 24.5 & $0.00 \%$ & 1.7 & $0.01 \%$ \\
\hline Stainless Steel & 335.7 & $0.10 \%$ & 24.4 & $0.13 \%$ & 591.2 & $0.12 \%$ & 48.3 & $0.18 \%$ \\
\hline Bricks & 9030.0 & $2.57 \%$ & 722.4 & $3.83 \%$ & 9030.0 & $1.80 \%$ & 722.4 & $2.67 \%$ \\
\hline Ceramic & 455.0 & $0.13 \%$ & 31.9 & $0.17 \%$ & 910.0 & $0.18 \%$ & 51.9 & $0.19 \%$ \\
\hline Concrete & 75.0 & $0.02 \%$ & 10.7 & $0.06 \%$ & 100.0 & $0.02 \%$ & 15.0 & $0.06 \%$ \\
\hline Glass & 74.8 & $0.02 \%$ & 3.8 & $0.02 \%$ & 97.5 & $0.02 \%$ & 5.9 & $0.02 \%$ \\
\hline Masonry & 6.1 & $0.00 \%$ & 1.0 & $0.01 \%$ & 6.1 & $0.00 \%$ & 1.0 & $0.00 \%$ \\
\hline Melamine & 485.0 & $0.14 \%$ & 21.0 & $0.11 \%$ & 485.0 & $0.10 \%$ & 21.0 & $0.08 \%$ \\
\hline Textile/Fabric & 488.4 & $0.14 \%$ & 25.7 & $0.14 \%$ & 488.4 & $0.10 \%$ & 25.7 & $0.10 \%$ \\
\hline Plastic & 3445.4 & $0.98 \%$ & 141.7 & $0.75 \%$ & 4078.8 & $0.81 \%$ & 160.9 & $0.60 \%$ \\
\hline PVC & 432.2 & $0.12 \%$ & 20.3 & $0.11 \%$ & 486.4 & $0.10 \%$ & 19.5 & $0.07 \%$ \\
\hline Plywood & 1249.4 & $0.36 \%$ & 37.5 & $0.20 \%$ & 1249.4 & $0.25 \%$ & 37.5 & $0.14 \%$ \\
\hline Timber & $70,125.3$ & $19.98 \%$ & 2173.9 & $11.52 \%$ & $112,200.5$ & $22.34 \%$ & 4067.3 & $15.05 \%$ \\
\hline Total & \multicolumn{2}{|c|}{$350,977 \mathrm{MJ}$} & \multicolumn{2}{|c|}{$18,862 \mathrm{~kg} \mathrm{CO}_{2 \mathrm{e}}$} & \multicolumn{2}{|c|}{$502,158 \mathrm{MJ}$} & \multicolumn{2}{|c|}{$27,029 \mathrm{~kg} \mathrm{CO} 2 \mathrm{e}$} \\
\hline
\end{tabular}

The study found that timber was the highest contributor in terms of material savings (58.2 per cent) followed by bricks ( 25 per cent), and aluminium (14.2 per cent). However, in terms of embodied energy savings, aluminium contributed the most - 75.37 per cent_followed by timber (19.98 per cent) and bricks (2.57 per cent). A total 350,977 MJ of embodied energy was potentially 
saved, and approximately $18,862 \mathrm{~kg}\left(\mathrm{CO}_{2 \mathrm{e}}\right)$ of carbon emissions were potentially reduced by recovering materials (by offsetting mixed material mix). Compared to offsetting virgin materials instead of mixed materials, approximately 502,158 MJ of embodied energy was potentially saved and around 27,029 kg $\left(\mathrm{CO}_{2 \mathrm{e}}\right)$ of carbon emission was potentially reduced.

Potentially, the WHR project saved around 139,488 kWh (1 megajoule $=0.277 \mathrm{kWh})$ of energy, which is equivalent to the annual electricity uses of six households in Christchurch. Simultaneously the amount of carbon emissions prevented by the WHR project can be equated to offsetting the annual emissions of six passenger cars in New Zealand. On this basis, the environmental benefits from the context of the 10,000 Christchurch homes that were declared fit for demolition in 2011 can be examined. Hypothetically, had a similar deconstruction approach as illustrated in the WHR project been implemented, around 5,021,580 gigajoule of energy ( 1 megajoule $=0.001$ gigajoule) could be saved and 270,290 tons of carbon emission could be potentially prevented.

Putting this finding in context, on July 2015, New Zealand set a national emission reduction targets under the United Nations Framework Convention on Climate Change, of 30\% below 2005 levels by 2030 (which equates to 11\% below 1990 levels). New Zealand also has a longer term target of reducing emissions to 50\% below 1990 levels by 2050 [59]. The WHR deconstruction project illustrates an alternative and innovative approach to $C \& D$ waste management, which can result in potentially significant, net economy-wide energy savings and reductions in carbon emissions which will contribute to achieving the national targets under the UNFCC.

The authors acknowledge the limitation of the study since the study mainly focused on the material recovery through deconstruction which is a fraction of the whole life cycle of the construction materials. Thus, the study would be benefited by considering an LCA/LCC along with a social-LCA analysis in the future.

\subsection{New Products and Socioeconomic Benefits from Harvested Materials}

The WHR project was not only limited to resource recovery from deconstruction, but included the facilitation of a comprehensive reuse phase, which resulted in the creation of a whole range of innovative products made from the recovered materials. The WHR project was sequenced in three distinct phases: 1-deconstruction of the house; 2-the creation of innovative products; and 3-a public exhibition, education, awareness raising, and auction of the products and art works remanufactured from recovered/harvested materials (NB: arguably a 4th aspect of this project can also be conceptualized in the ongoing work of Rekindle in initiating follow-on projects which seek to build on and expand the scope of demonstration, research/learning, and communication around the value of $C \& D$ recovery reuse and recycling. After the completion of the house dismantling process, the deconstructed materials were stored for the next phase of project activities. The 2 nd creative reuse phase of the project involved 282 designers, artisans, builders, and craftspeople and around 400 objects were produced from the material resources harvested during the deconstruction phase of the WHR project. Figure 4 shows the new products created by various designers. 

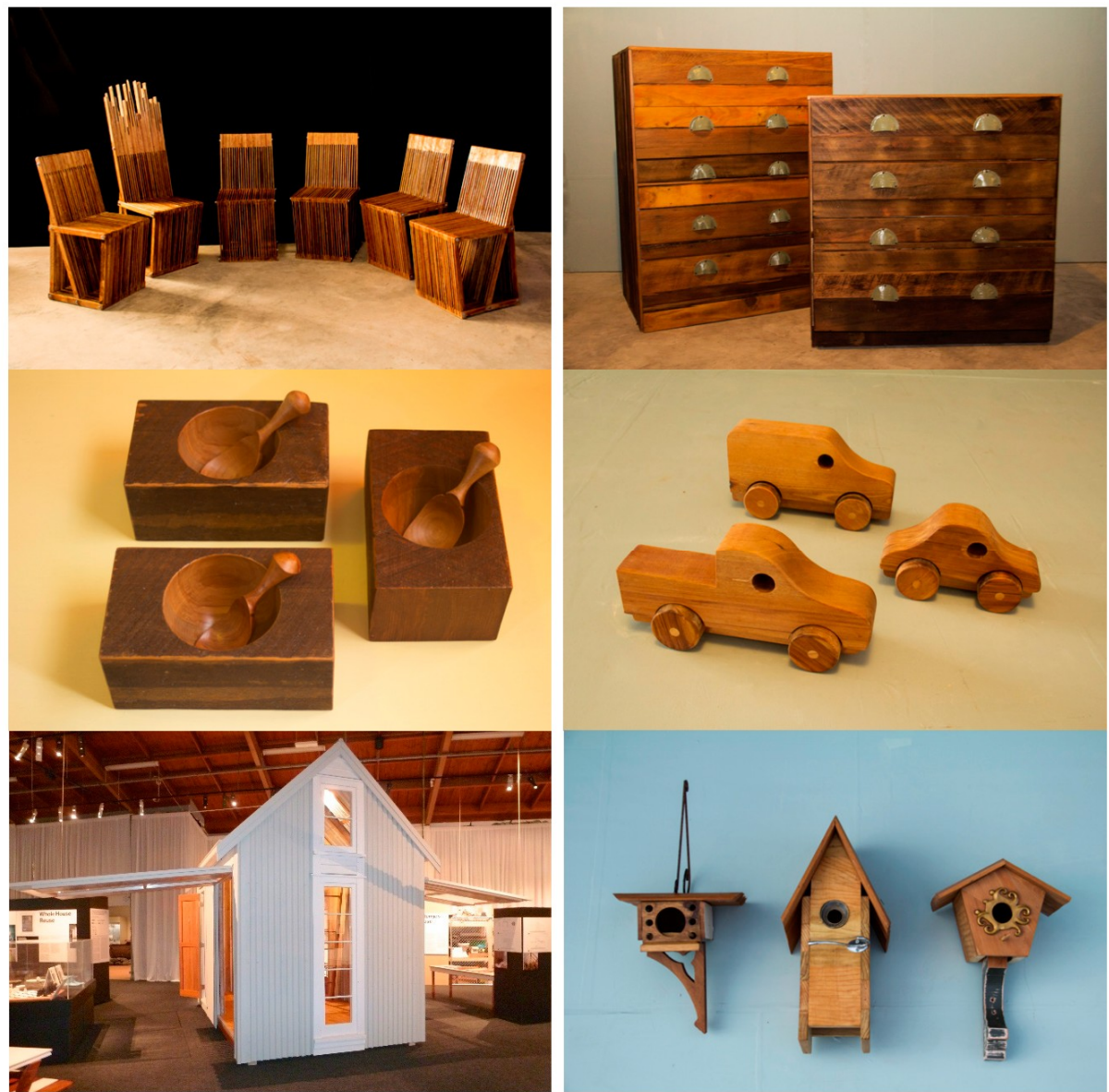

Figure 4. New products from harvested materials (Courtesy: Guy Frederick). Designers in Top left: Tim McGurk and Trudo Wylaars and top right: Annelies Zwann. Middle left: Soren Berger and middle right: Klaus Rachuy. Bottom left: Nic Moon and Lyn Russell and bottom right: Kirsten Wilson.

The WHR project significantly relied on the voluntary work contributed by local community and artists. Indicative of this commitment, approximately $1105.5 \mathrm{~h}$ were recorded (for 52 products) as being spent to produce 52 objects i.e., an average $21 \mathrm{~h}$ of time spent for each object that local artists had spent to create new products from the recovered materials. As part of the 3rd exhibition-auction phases of the WHR project 122 of the created objects were sold for a total of NZD $\$ 43,425$. Whilst this demonstrates a strong financial outcome (along numerous other social, cultural, and environmental attributes) it can be recognized that when evaluated by a singular economic metric the project may not be $100 \%$ financially viable on a stand-alone basis under current market conditions. However, the project indicates that with the involvement of local community's artists and environmentalists, the project demonstrated high social engagement with big picture 'ethos' of the project via a considerable investment of time, enabling labor cost to be minimized.

The net result of this diverse community investment of collaborative creativity, artistic/design, technical skills, and innovation, resonated far beyond the resulting products and their attributed economic value and manifested in a widespread, high-profile, and demonstrable understanding of the process and value of deconstruction and reappreciation of upcycling value from otherwise wasted material resources. As such, the WHR project raises important questions which have reverberated beyond the local, into the national conversation around waste and resource management policy. For example, New Zealand's landfill levy is an important economic instrument designed to discourage disposal and incentivize recycling. Recent calls to increase the waste levy raise debate $[20,60,61]$ as to the impact of such instruments in improving the viability (i.e., examined as a whole of material 
lifecycle cost-benefit analysis inclusive of environmental social and financial measures) of the spectrum of activity demonstrated in the WHR project.

The WHR project can also be considered successful in engaging both the immediate participants and the wider local communities in preserving, through deconstruction and reusing the attachment, the dignity of this 'house', as emblematic of all that were lost and demolished. Deconstruction and reuse not only provides resource recovery, but also rehabilitates and values the memories and personal connection with the physical materials, space, and time housed in our construct of home. The owners of the case study project have vast memories around the house. In a conversation, the owners of the property stated, "that was the place we brought our two boys back after they were born and we had fantastic birthday parties and different moments there". Thus, by harvesting resources and creating new products from the dismantled materials, their emotional attachment with the property was preserved and, in a sense, remade, revalued, and shared with others. In this sense the WHR project must be viewed alongside the broader landscape of postearthquake business, welfare, arts, heritage, and environment recovery initiatives, such as: 'Restart', 'Regenerate', 'CanCERN', Rebuild Christchurch, 'Gap-filler' initiative, 'Greening the rubble', and CEISMIC (digital archive-including 'Quakes Stories' \& 'Kete Christchurch')—is designed to preserve the memories and experiences of people of the Canterbury region), 'Life in Vacant Spaces' (see: https:/ / my.christchurchcitylibraries.c om/earthquake-recovery-information)

\subsection{Lessons Learnt from the Whole House Reuse Project}

The WHR project highlighted the significant difference between conventional demolition and the alternative option of deconstructing and reusing the material resources contained in residential houses. Most of the materials recovered in the WHR would have ended up in landfill, had the conventional destructive mechanical demolition methods been applied. The WHR project not only harvested materials from house, but also conserved resources by producing new products and partially preserved the emotional attachment of the house through the artworks.

Based on the findings of this study, it cannot be concluded that the project was economically viable, but the project was successful in the context of social engagement and ensuring environmental benefits. The project has significant implications in respect to contemporary efforts in realizing a more circular economy. In particular, the project highlights mechanism for engaging volunteering community and business collaboration, creative design, and art-based upcycling and insight into high value 'recycle' market development which ultimately drives the financially sustainable recirculation of resources within the material supply chain. However, the project would have been more financially successful if the existing economic system sought to support deconstruction activities by employing market-based regulatory and economic instruments to internalize otherwise ignored externalized costs, such as unnecessary GHG emissions, natural resource exploitation, and other forms of environmental pollution.

The key challenges and barriers that can be expected in seeking to facilitate future/further deconstruction-reuse projects to build on the WHR experience and outcomes are:

- Finding appropriately experienced skilled volunteers with available time and suitable commitment for the deconstruction phase activities.

- Temporary storage of harvested materials.

- Maximizing the resale value of reusable resources and new remade products.

- Strategic commitments and national policy frameworks which enable local authorities and relevant business and community groups to grow deconstruction and reuse activity.

The authors propose following recommendations to make deconstruction practices more economically viable in New Zealand: 
- Deconstruction of old houses should be identified and supported by directing the local WMMPs and regulatory tools to establish targets, incentives, and data collection to motivate the dismantling and conservation of resources embodied in the built environment, ahead of mass demolition.

- Undertake further research to better understand both the externalized costs (including all forms of environmental exploitation and pollution) associated C\&D waste disposal (vs. recovery, reuse, and recycling), alongside evaluating the sociocultural benefits (such as contribution to social resilience) and building practical local knowledge, skill, and experience round around alternatives, such as deconstruction and reuse and upcycling.

- In accordance with the current industry and local government calls, an increase in the landfill disposal tax/levy to further promote waste minimization activities and in concert, on the basis of international good practice concert evaluate opportunities to better utilize the 'Waste Minimization Fund (WMF) to create a financially sustainable deconstruction-material reuse sector as a key driver for of a zero-waste based circular economy.

- Consultatively develop a comprehensive, politically multilateral, deconstruction-reuse strategy, which is integrated with broader policy on C\&D waste minimization (which is aligned under the national waste reduction targets) and review and revise this based upon the ongoing learnings from practical experience and R\&D.

- Develop an aligned International-National Disaster Waste Strategy which ensures the economic, environmental, and social welfare and cultural benefits of deconstruction and material reuse forms an appropriate part of emergency response and regeneration training, technical/infrastructural capacity, and responder/community activities.

- Foster New Zealand's social entrepreneurs, the artisan/design, and building and construction sector and the zero waste community enterprise network and the general public and ensure they have an understanding of the holistic value of material reuse and upcycling, and access to globalized creative inspiration, practical 'how to' guidance, a constant flow of high quality harvested resources from across the material product spectrum, access to viable recycle markets, and necessary start-up funding and capital.

- Undertaken further research to scientifically quantify recycling related GHG emission reductions and to ensure this activity is recognized and aligned within national climate change mitigation and sustainable development strategies and ensure appropriate further economic (such as product stewardship/extended producer responsibility approaches) and social instruments incentivize achieving these beneficial outcomes.

- Ensuring appropriate deconstruction occupational safety and health and reused material quality standards and practical guidelines are developed and implemented [32].

\section{Conclusions}

The study presented a case study entitled the 'Whole House Reuse' (WHR) project from Christchurch, New Zealand, involving deconstruction and material reuse of resources embodied in a family house. The project illustrated both the challenges and opportunities in deconstruction processes. Although the deconstruction process has a considerable potential for material recovery and environmental benefits, under current socioeconomic and environmental policy settings, the associated labor costs versus resale value of the harvested and remade items significantly influence the viability of a deconstruction project.

The case study established that over twelve tons of recyclable materials were able to be harvested from the subject building. Under a business as usual scenario, in the absence of applying the WHR deconstruction practices it would be expected that most of the recovered resources would have ended-up in landfill. The study estimated that the recovered and reused materials involved in the WHR project could potentially save around 502,158 MJ of embodied energy and prevent carbon emission of around $27,029 \mathrm{~kg}\left(\mathrm{CO}_{2 \mathrm{e}}\right)$. Projecting this estimate across a scenario whereby all 10,000 houses which were damaged in the 2010-2011 Christchurch earthquakes were deconstructed for material to be 
reused rather than subjected to mechanical destruction/disposal typical of conventional demolition, a total of 5,021,580 gigajoule of energy could be saved and 270,290 tons of carbon emissions could be potentially prevented.

Whilst it is not suggested that in the real-world context of postearthquake Christchurch City, a total deconstruction option may not have been feasible, clearly this projection establishes the value proposition of greater consideration being given to deconstruction and material reuse, rather than as occurred, wholesale destructive demolition and disposal. One of the key reasons for not implementing deconstruction in a wider scale in Christchurch appears to be due to a lack of consistent policy, regulatory, and economic support from the government. Arguably, this omission relates to a lack of understanding of the real world practicality, popularity, proven legal/regulatory frameworks, social engagement and community welfare benefits, and strong environmental and economic outcomes associated with well-designed C\&D waste minimization strategies [62]. This omission coincides with an observable deficit in New Zealand based peer-reviewed scientific research in the sphere of C\&D waste minimization $[63,64]$. This article seeks to illustrate these beneficial outcomes and to call for further investment in interdisciplinary case study research to expand on and further quantify this important knowledge area.

It is also important to contextualize the WHR project period (2013-2015) inside to overarching New Zealand 'wastescape', which includes a pronounced polarity in waste policy between the center left, Labor led (1999-2008, re NZWS: 2002 i.e., emphasizing zero waste and sustainable development) and the subsequent center right, National led (2008-2017, re NZWS: 2010 i.e., emphasizing economic growth) periods of coalition government. The WHR project occurred in the latter policy phase, typified by a free-market, business centric, non-interventionist government ideology. The net result of that less environmentally assertive policy phase is that, in spite of a national waste levy raising more than "\$192 million-which has been distributed to national and local initiatives to reduce waste", the opposite has occurred and "the net tonnages of waste reported at levied waste disposal facilities, increased by $20.1 \%$ in the three years between the 2014 and 2017" [65]. New Zealand's apparent omissions in properly appreciating and engaging the learnings from the WHR (and more broadly the whole sphere of international good practice in C\&D waste minimization activity) must be seen as a subset of an overarching period of public policy failure, which has seen per person waste generation rates increase to become amongst "the highest in the OECD—each New Zealander produces an average of $734 \mathrm{~kg}$ waste per year" [66].

Given this data, it now appears that a suitable junction in which to not only reappraise the WHR project outcomes within New Zealand's relatively limited and sporadic C\&D waste minimization program experience, but to assert on the basis of these indicative data, alongside emerging international good practice and the associated research findings, the value of this entire work area as a driver for zero waste and a circular economy. The study indicated that deconstruction-material reuse may not be completely economically viable under current market conditions, but considering the greater socioeconomic aspects and overall environmental benefits in regard to energy savings and abatement of carbon reduction aligned with the national emission reduction targets, a strategic national approach to deconstruction and material reuse appears to offer considerable benefit over the conventional baseline of just demolition-disposal.

Realizing the potential of deconstruction and material reuse, as part of an integrated national C\&D waste minimization strategy, will benefit from understanding this work area as integrated with related nationally strategic considerations (such as, for example, disaster waste management, build community resilience, reducing GHG emissions, climate change mitigation, engaging environmental sustainable design in the built environment, and cultivating upcycling and recycling market development as a driver for a circular economy); designing ongoing local $R \& D$, integrated with and drawing upon emerging international good practice to inform New Zealand's waste policy and programs, specific national and local WMMP targets (monitored and reported), proactive and nationally coordinated policy, and regulatory instruments (include PS/EPR) 'prioritizing'; and addressing C\&D waste and 
capacity building interventions to support the requisite, human resource (especially social enterprise and the community sector) and technical infrastructure for successful C\&D waste minimization.

Given that New Zealand's experience and data show the negative consequences of failing to be environmentally assertive, via an effective, scientific, practice-informed national C\&D waste minimization strategy, the authors argue it is now time for these omissions to be rectified. The WHR project experience indicates that there are a wide range of alternative opportunities to address $C \& D$ waste issues which will result in alternative business models involving the local community and growing interest and commitment from local authorities to understand and implement 'enabling platforms' locally, reduced net energy consumption, GHG emissions, other environmental pollution, and unnecessary natural resource exploitation, whilst progressing towards zero waste and more sustainable, circular economic development.

Author Contributions: J.A. and K.M. conceived the project idea and designed and implement the deconstruction process. A.U.Z. analyzed the data and wrote the article with the help of J.A., K.M. and J.H.

Funding: This research received no external funding.

Acknowledgments: This article is primarily based on the data of the Whole House Reuse project supported by the Sustainable Initiatives Fund Trust, Creative Communities, and Jamon Construction Ltd.; the project was instigated and facilitated by Rekindle. The authors declare no conflict of interest with anybody regarding this article. The authors would like to thank the reviewers for their insightful comments.

Conflicts of Interest: The authors declare no conflicts of interest.

\section{References}

1. Schandl, H. How Do We Uncouple Global Development from Resource Use? 2016. Available online: https://theconversation.com/how-do-we-uncouple-global-development-from-resource-use-62730 (accessed on 21 July 2016).

2. UNEP. Global material flows and resource productivity. In Assessment Report for the UNEP International Resource Panel; UNEP: New York, NY, USA, 2016.

3. Downes, J. We can't Recycle our Way to 'Zero Waste'. Available online: https://theconversation.com/we-c ant-recycle-our-way-to-zero-waste-78598 (accessed on 20 September 2018).

4. EEA. Circular Economy in Europe-Developing the Knowledge Base. 2016. Available online: http://www.ee a.europa.eu/publications/circular-economy-in-europe (accessed on 20 May 2017).

5. ABS. Construction and the Environment: Year Book Australia, 2003; Australian Bureau of Statistics: Canberra, Australia, 2003.

6. UNEP-SBCI. Building Design and Construction: Forging Resource Efficiency and Sustainable Development. In United Nations Environment Programme-Sustainable Buildings and Climate Initiative; UNEP-SBCI: New York, NY, USA, 2012.

7. Cuéllar-Franca, R.M.; Azapagic, A. Environmental impacts of the UK residential sector: Life cycle assessment of houses. Build. Environ. 2012, 54, 86-99. [CrossRef]

8. Dahlstrøm, O.; Sørnes, K.; Eriksen, S.T.; Hertwich, E.G. Life cycle assessment of a single-family residence built to either conventional-or passive house standard. Energy Build. 2012, 54, 470-479. [CrossRef]

9. Mcardle, M. Are There Too Many Homes in America? 2011. Available online: https://www.theatlantic.com/ business /archive/2011/06/are-there-too-many-homes-in-america/240786/ (accessed on 26 July 2018).

10. US-EPA. Sustainable Management of Construction and Demolition Materials. 2018. Available online: https://www.epa.gov/smm/sustainable-management-construction-and-demolition-materials\#America (accessed on 30 June 2018).

11. Diyamandoglu, V.; Fortuna, L.M. Deconstruction of wood-framed houses: Material recovery and environmental impact. Resour. Conserv. Recycl. 2015, 100, 21-30. [CrossRef]

12. NAHB. A Guide to Deconstruction, National Association of Home Builders; Department of Housing and Urban Development: Washington, DC, USA, 2000.

13. Chini, A.R. (Ed.) Deconstruction and Materials Reuse-An International Overview; Final Report of Task Group 39 on Deconstruction; International Council for Research and Innovation in Building Construction: Gainesville, FL, USA, 2005. 
14. Couto, J.; Couto, A. Analysis of barriers and the potential for exploration of deconstruction techniques in Portuguese construction sites. Sustainability 2010, 2, 428-442. [CrossRef]

15. Level. Material Use: The Authority on Sustainable Building. 2014. Available online: http://www.level.org. $\mathrm{nz} /$ material-use/minimising-waste/ (accessed on 25 June 2016).

16. Storey, J.; Gjerde, M.; Charleson, A.; Pedersen, M. The State of deconstrcution in New Zealand 2003-Synopsis. In Whole House Reuse: Deconstruction; Arnott, J., McIntyre, K., Eds.; Rekindle: Christchurch, New Zealand, 2014.

17. Storey, J.B.; Pedersen, M. Overcoming the barriers to deconstruction and materials reuse in New Zealand. In Barriers for Deconstruction and Reuse/Recycling of Construction Materials; Nakajima, S., Ed.; CIB Publication: Delft, The Netherlands, 2014.

18. MfE. The New Zealand Waste Strategy: Reducing Harm, Improving Efficiency (NZWS:2010); MfE: Wellington, New Zealand, 2010. Available online: http://www.mfe.govt.nz/sites/default/files/wastestrategy.pdf (accessed on 25 May 2017).

19. Hannon, J. (Un) Changing Behaviour: (New Zealand's Delay \& Dysfunction in Utilising) Economic Instruments in the Management of Waste? New Zealand Product Stewardship Council: Palmerston North, New Zealand, 2018.

20. WasteMINZ. Local Government Waste Management Manifesto: Developed by the Territorial Authority Forum, a Sector Group of WasteMINZ; WasteMINZ: Auckland, New Zealand, 2018.

21. Inglis. Construction and Demolition Waste-Best Practice and Cost Saving, Ministry of Environment. Available online: http://www.cmnzl.co.nz/assets/sm/2260/61/057-INGLISMahara.pdf (accessed on 6 June 2016).

22. Paterson, C.J. Report on a Sorting Trial of Construction Bin Waste as Part of Stage 2 of Project CED; Auckland Regional Council (ARC) Environment: Auckland, New Zealand, 1997.

23. Farrelly, T.; Tucker, C. Action research and residential waste minimisation in Palmerston North, New Zealand. Resour. Conserv. Recycl. 2014, 91, 11-26. [CrossRef]

24. Parliamentary Council Office. Waste Minimisation Act 2008. Available online: http://www.legislation.go vt.nz/act/public/2008/0089/latest/whole.html?search=ts_act_waste_resel\&p=1\#DLM1154501 (accessed on 24 June 2018).

25. MfE. Related Waste Legislation. 2015. Available online: http://www.mfe.govt.nz/waste/waste-strategy-a nd-legislation/related-waste-legislation (accessed on 7 February 2017).

26. ZWNZ Trust. What is Zero Waste? Zero Waste New Zealand Trust, Kaipatiki Project. Auckland. Available online: http:/ / www.zerowaste.co.nz/ zero-waste-1/about-us-2/ (accessed on 12 July 2015).

27. Hannon, J. Waste vs. zero waste: The contest for engaging and shaping our ambient 'waste-making' culture. In Unmaking Waste 2015: Transforming Production and Consumption in Time and Place; Zero Waste SA Research Centre for Sustainable Design and Behaviour and the University of South Australia: Zero Waste, SA, USA, 2015.

28. Seadon, J.K.; Griffin, J. Reducing Construction and Demolition Waste via Deconstruction and Reuse; WasteMINZ: Auckland, New Zealand, 2016.

29. Go, T.; Wahab, D.A.; Rahman, M.A.; Ramli, R.; Azhari, C.H. Disassemblability of end-of-life vehicle: A critical review of evaluation methods. J. Clean. Prod. 2011, 19, 1536-1546. [CrossRef]

30. Carvalho Machado, R.; Artur de Souza, H.; de Souza Veríssimo, G. Analysis of Guidelines and Identification of Characteristics Influencing the Deconstruction Potential of Buildings. Sustainability 2018, 10, 2604. [CrossRef]

31. Minunno, R.; O'Grady, T.; Morrison, G.; Gruner, R.; Colling, M. Strategies for Applying the Circular Economy to Prefabricated Buildings. Buildings 2018, 8, 125. [CrossRef]

32. Lipscombe, F.; Kneebone, P. CED Waste Crafting a Powerful Ecolabel: A Call for Input; Waste Management Institute of New Zealand: Hamilton, New Zealand, 2017.

33. Dantata, N.; Touran, A.; Wang, J. An analysis of cost and duration for deconstruction and demolition of residential buildings in Massachusetts. Resour. Conserv. Recycl. 2005, 44, 1-15. [CrossRef]

34. Höglmeier, K.; Weber-Blaschke, G.; Richter, K. Potentials for cascading of recovered wood from building deconstruction-A case study for south-east Germany. Resour. Conserv. Recycl. 2013, 78, 81-91. [CrossRef]

35. LEVEL and BRANZ. Minimisting and Reusing and Recycling C\&D Waste. Available online: http://www.le vel.org.nz/material-use/minimising-waste/ (accessed on 20 September 2018).

36. Burns, P. Waste Minisation in the Construction Industry; WasteMINZ: Auckland, New Zealand, 2001.

37. Hanne, S.; Boyle, C. Source Separation of Construction Wastes in New Zealand; WasteMINZ: Auckland, New Zealand, 2001. 
38. Crutchley, K.; Purchas, C. Construction and Demolition Waste-What Can We DO about It? North Shore City Council \& MfE: Auckland, New Zealand, 2005.

39. Inglis, M. Construction and Demolition Waste: Best Practice and Cost Saving; MfE: Wellington, New Zealand, 2007.

40. REBRI. REBRI Guide: Construction Waste Reduction; REBRI: Auckland, New Zealand, 2005.

41. REBRI. REBRI Guide: Demolition Waste Reduction; BRANZ \& MfE: Auckland, New Zealand, 2005.

42. Berry, C. Residential Construction Waste Reduction: Case Studies and Resources; Ryan, V., Ed.; Beacon Pathway Incorporated: Auckland, New Zealand, 2014.

43. Mauro, John, Auckland Council. Demystifying Deconstruction and Reuse; WasteMINZ: Auckland, New Zealand, 2015. Available online: https://www.wasteminz.org.nz/wp-content/uploads/WasteMINZ-2015-Demys tifying-Deconstruction.pdf (accessed on 25 September 2018).

44. The Sustainable Business Network. The Circular Economy Opportunity for Auckland and How Business Can Realise It; SBN-NZ: Auckland, New Zealand, 2017. Available online: https://static1.squarespace.com/static/59d8312 f268b96ed79bdadc3/t/5af25e570e2e729b66cb31ea/1525833380771/SBN_CircularEconomyOpportunity_Fo rAuckland.pdf (accessed on 25 September 2018).

45. Ellen MacArthur Foundation. Towards the circular economy 1: Economic and business rationale for an accelerated transition. In Rethink the Future; Ellen MacArthur Foundation: Cowes, UK, 2013.

46. EMF. Circular Economy Overview. 2015. Available online: http://www.ellenmacarthurfoundation.org/cir cular-economy / overview / concept (accessed on 12 November 2017).

47. Kellner, J. Housing Reclaimed: Sustainable Homes for Next to Nothing; New Society Publishers: Gabriola Island, BC, Canada, 2011.

48. Guy, B.; McLendon, S. Building Deconstruction: Reuse and Recycling of Building Materials; Florida Department of Environmental Protection: Gainesville, FL, USA, 2000.

49. Guy, B. Building Deconstruction: Reuse and Recycling of Building Materials. 2000. Available online: http:/ / www.lifecyclebuilding.org/docs/Six\%20House\%20Building\%20Deconstruction.pdf (accessed on 20 July 2018).

50. Falk, B. Wood-framed building deconstruction: A source of lumber for construction? For. Prod. J. 2002, 52, 8-15.

51. Denhart, H. Deconstructing disaster: Economic and environmental impacts of deconstruction in post-Katrina New Orleans. Resour. Conserv. Recycl. 2010, 54, 194-204. [CrossRef]

52. Forsythe, P.J. Drivers of housing demolition decision making and the impact on timber waste management. Constr. Econ. Build. 2011, 11, 1-14. [CrossRef]

53. Lipsey, M.W. Personal Antecedents and Consequences of Ecologically Responsible Behavior: A review. Am. Psychol. Ass. J. Suppl. Abstr. Serv. 1977, 7, 70.

54. Oskamp, S.; Harrington, M.J.; Edwards, T.C.; Sherwood, D.L.; Okuda, S.M.; Swanson, D.C. Factors influencing household recycling behavior. Environ. Behav. 1991, 23, 494-519. [CrossRef]

55. Hammond, G.; Jones, C. Inventory of Carbon and Energy (ICE) Version 2.0. Sustainable Energy Research Team 2011. Available online: www.carbonsolutions.com/Resources/ICE\%20V2.0\%20-\%20Jan\%202011.xls (accessed on 12 February 2018).

56. Arnott, J.; McIntyre, K. (Eds.) Whole House Reuse: Deconstruction; Rekindle: Christchurch, New Zealand, 2014.

57. Nnorom, I.; Ohakwe, J.; Osibanjo, O. Survey of willingness of residents to participate in electronic waste recycling in Nigeria-A case study of mobile phone recycling. J. Clean. Prod. 2009, 17, 1629-1637. [CrossRef]

58. Schultz, P.W.; Oskamp, S. Effort as a moderator of the attitude-behavior relationship: General environmental concern and recycling. Soc. Psychol. Q. 1996, 59, 375-383. [CrossRef]

59. UNFCCC. New Zealand's Intended Nationally Determined Contribution. 2015. Available online: http:/ / www4.unfccc.int/submissions/INDC/Published\%20Documents/New\%20Zealand/1/New\%20Z ealand\%20INDC\%202015.pdf (accessed on 20 June 2017).

60. Wilson, D. A Wasted Opportunity: The Case for Changing the Waste Levy; Eunomia Research and Consulting: Auckland, New Zealand, 2017.

61. WasteMINZ. The Waste Disposal Leoy: What WasteMINZ Members Think; Waste Management Institute of New Zealand: Auckland, New Zealand, 2016.

62. Del Río Merino, M.; Navarro, J.G.; Sáez, P.V. Legal aspects which implement good practice measures in the management of construction and demolition waste. Open Constr. Build. Technol. J. 2011, 5, 124-130. [CrossRef] 
63. Lu, W.; Yuan, H. A framework for understanding waste management studies in construction. Waste Manag. 2011, 31, 1252-1260. [CrossRef] [PubMed]

64. Yuan, H.; Shen, L. Trend of the research on construction and demolition waste management. Waste Manag. 2011, 31, 670-679. [CrossRef] [PubMed]

65. MfE. Review of the Effectiveness of the Waste Disposal Levy 2017; New Zealand Ministry for the Environment: Wellington, New Zealand, 2017.

66. MfE. Briefing to the Incoming Minister for the Environment: 'ENVIRONMENT PORTFOLIO'; Ministry for the Environment: Wellington, New Zealand, 2017.

(C) 2018 by the authors. Licensee MDPI, Basel, Switzerland. This article is an open access article distributed under the terms and conditions of the Creative Commons Attribution (CC BY) license (http:/ / creativecommons.org/licenses/by/4.0/). 